\title{
Focused series on interventional pulmonology and advanced bronchoscopy
}

We are pleased to present the readers of Shanghai Chest with this focused series covering updates and advances in the field of interventional pulmonology (IP) and advanced bronchoscopy. Since first being recognized as a distinct subspecialty by Seijo and Sterman in 2001, IP has experienced tremendous growth (1). Today, IP providers around the world provide minimally invasive management of diseases affecting the lungs, airways, and pleura. Numerous international professional organizations have been born to support providers in this field (2). Rapid development of new equipment and techniques have necessitated that providers continually expand and refresh their knowledge and skill set in order to provide the most up-to-date care for their patients.

This focused series was designed to provide readers with state-of-the-art reviews on several classic topics with recent advances, as well as cutting-edge areas that are still maturing. A select group of experts in the field were asked to contribute on specific topics based on their expertise and prior publication track-record. Topics were selected based on their relevance and perceived usefulness for the diverse readership of Shanghai Chest.

Dr. Jasleen Pannu from The Ohio State University contributed a review of transbronchial cryobiopsy. She provides a practical step-by-step guide emphasizing the proper technique, as supported by recent guidelines (3).

The recent introduction of robotic bronchoscopy has prompted some providers to question the future viability of traditional navigational bronchoscopy systems. Dr. Amit "Bobby" Mahajan from Inova Fairfax Hospital provides insight into the key factors supporting each side of the equation. This topic will likely become increasingly relevant as robotic technology is refined and becomes more affordable.

Airway complications following lung transplantation continue to represent a management challenge, even for experienced providers. Dr. Laura Frye from the University of Wisconsin clearly delineates the various tools and techniques employed to handle these situations based on patient-specific factors.

New advances in the management of central airway obstruction are examined by Dr. Kevin Ma from the University of Pennsylvania. Dr. George Cheng from the University of California San Diego reveals new stent types and techniques for relief of malignant and benign airway stenosis.

Together, these articles form an excellent resource for all interventional pulmonologists and advanced bronchoscopists. They offer recommendations that are based on data and endorsed by leaders in the field. We look forward to feedback from the readers of Shanghai Chest so that we may continue to provide high-quality, relevant publications in the future.

\section{Acknowledgments}

Funding: None.

\section{Footnote}

Provenance and Peer Review: This article was commissioned by the editorial office, Shanghai Chest for the series "Interventional Pulmonology and Advanced Bronchoscopy". The article did not undergo external peer review.

Conflicts of Interest: Both authors have completed the ICMJE uniform disclosure form (available at http://dx.doi.org/10.21037/ shc-2019-ipab-16). The series "Interventional pulmonology and advanced bronchoscopy" was commissioned by the editorial office without any funding or sponsorship. JSK and DKH served as the unpaid Guest Editors of the series. DKH serves as an unpaid editorial board member of Shanghai Chest from Jan 2019 to Dec 2020. JSK reports personal fees from Level Ex, 
personal fees from Medtronic, other from Pinnacle Biologics, personal fees from Biodesix, outside the submitted work. DKH reports personal fees and other from Auris, personal fees from Ambu, personal fees, non-financial support and other from Body Vision, personal fees and other from Eolo, other from Eon, other from Gravitas, personal fees and other from Noah Medical, personal fees and other from LX-Medical, other from Med-Opsys, other from Monogram Orthopedics, personal fees and other from Preora, other from VIDA, other from Viomics, personal fees from Boston Scientific, personal fees from Johnson and Johnson, personal fees from oncocyte, personal fees from veracyte, personal fees and other from Broncus, grants and personal fees from Gala, personal fees from Heritage Biologics, personal fees from IDbyDNA, personal fees from LevelEx, personal fees from Medtronic, personal fees from Neurotronic, personal fees from olympus, personal fees from PulmonX, personal fees from Astra-Zeneca, personal fees from Biodesix, personal fees from Genetech, personal fees from Grifols, personal fees from Takeda, personal fees from CSL, personal fees from InhibRX, outside the submitted work; None of these COI have anything to do with this paper or Dr. Hogarth's work on this paper. The authors have no other conflicts of interest to declare.

Ethical Statement: The authors are accountable for all aspects of the work in ensuring that questions related to the accuracy or integrity of any part of the work are appropriately investigated and resolved.

Open Access Statement: This is an Open Access article distributed in accordance with the Creative Commons AttributionNonCommercial-NoDerivs 4.0 International License (CC BY-NC-ND 4.0), which permits the non-commercial replication and distribution of the article with the strict proviso that no changes or edits are made and the original work is properly cited (including links to both the formal publication through the relevant DOI and the license). See: https://creativecommons.org/licenses/by-nc$\mathrm{nd} / 4.0 \%$.

\section{References}

1. Seijo LM, Sterman DH. Interventional pulmonology. N Engl J Med 2001;344:740-9.

2. Hogarth DK, Mahajan AK. The Society for Advanced Bronchoscopy: An Introduction. Chest 2019;155:1092-4.

3. Maldonado F, Danoff SK, Wells AU, et al. Transbronchial Cryobiopsy for the Diagnosis of Interstitial Lung Diseases: CHEST Guideline and Expert Panel Report. Chest 2020;157:1030-42.

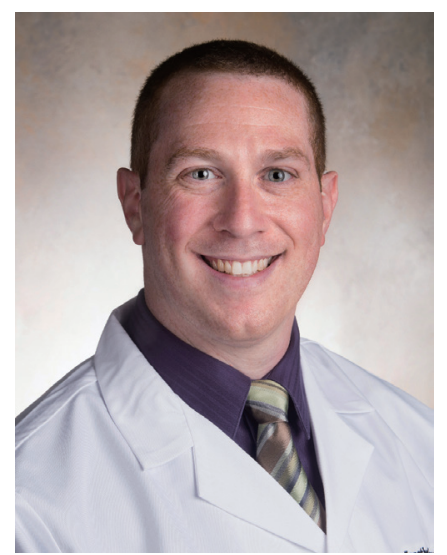

Jonathan S. Kurman, MD.

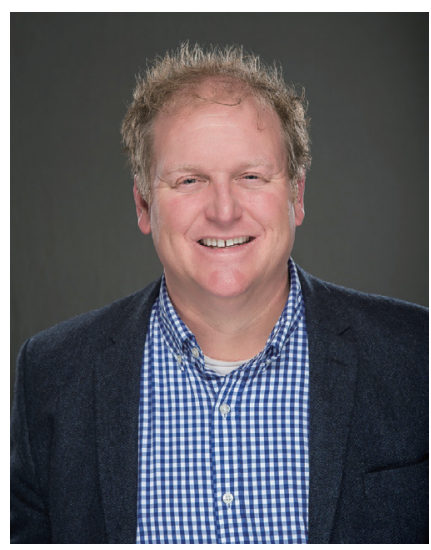

D. Kyle Hogarth, MD. 
Jonathan S. Kurman, $\mathbf{M D}^{1}$

${ }^{1}$ Division of Pulmonary \& Critical Care, Medical College of Wisconsin, Milwaukee,WI, USA. (Email:jkurman@mow.edu)

D. Kyle Hogarth, $\mathbf{M D}^{2}$

${ }^{2}$ Section of Pulmonary \& Critical Care, University of Chicago Medicine,

Chicago, IL, USA. (Email: khogarth@medicine.bsd.uchicago.edu)

Received: 20 April 2020. Accepted: 12 May 2020; Published: 10 October 2020.

doi: 10.21037/shc-2019-ipab-16

View this article at: http://dx.doi.org/10.21037/shc-2019-ipab-16

doi: 10.21037/shc-2019-ipab-16

Cite this article as: Kurman JS, Hogarth DK. Focused series on interventional pulmonology and advanced bronchoscopy.

Shanghai Chest 2020;4:36. 